\title{
ON THE BEACH: MYTH, FALCONRY, AND THE END OF THE SOLEDADES
}

\section{Carroll B. Johnson}

University of California, Los Angeles

Thave always been fascinated by the distantly observed aristocratic hawking party on a deserted beach where the Soledades end, Lwith its final, Fellini-esque image of the solitary owl taking his lumbering flight. Various critics have offered various readings of the episode. Robert Jammes sees an aspect of the corte-aldea tension (132). For John Beverley "the violence of the hawking scenes is intended as an allegory of war" (Aspects 93). Gwynne Edwards sees in the hawking scene an exploitation of the violence existing in Nature by humans, for their own amusement, in the course of which "the activities of the nobles are thrown into a perspective which is a total condemnation" (242). The most extreme vision belongs to Crystal Chemris, who reads the falconry scene as the "thematic realization of the topos of the end of the world, the end of this time and space" ("Time, Space and Apocalypse" 148). Many critics have seen some relation between the hawking scene and Góngora's conflicted relation to the Duque de Lerma and his Andalusian relatives; nearly all invoke the myth of Persephone-Proserpina; and just about everyone (with the notable exception of Beverley) considers the poem unfinished, that it merely stops as the owl takes flight in the final verse. I want to pursue some of these lines of investigation in the direction of an allegorical reading focused on the poet and poetry, which will also suggest a hypothesis concerning the sense of an ending.

Let us come back to the owl and his solitary flight. Góngora evokes the owl indirectly, as a metaphor, via a minor but crucial aspect of a myth, in the person of Ascalaphus, the sole witness of the "dulce hija" Proserpina's marriage to the "stigia Deidad" Pluto, transformed into the owl as punishment, either by Proserpina herself, or in some versions by her mother, the "sicana Diosa" Ceres. The owl had already appeared, in connection with the same story, in the first Soledad, as "Ascálafo, vestido / de perezosas plumas" (990-91).

The story of Demeter and Persephone, or in Góngora's Latinized version, of Ceres and Proserpina, has become a classic exemplar of mother-daughter solidarity in the feminist redrawing of the oedipal triangle. I offer a brief summary as a first step toward contextualizing 
the appearance of the owl at the end of Góngora's poem.

Ceres-Demeter was the goddess of cereal products. She became the mother of Proserpina-Persephone by Jupiter-Zeus. Unbeknownst to Ceres, Jupiter had promised Proserpina to his brother Pluto-Hades, god of the underworld. Accordingly, she was swallowed up by the earth and disappeared. Her special name in Attic cult is Kore (literally "the maiden"). It was as a maiden, while plucking flowers near Enna in Sicily, according to the story common in Roman times, that she was carried off into the lower world. When Ceres found out she had lost her daughter, she left Olympus to dwell with people, but was so angry that she refused to let the earth bear fruit. Jupiter, thereupon, sent Mercury-Hermes to bring Proserpina back to her mother. Pluto agreed, but gave Proserpina a pomegranate to eat before she left. Ceres and Proserpina returned to Olympus, but since Proserpina had eaten the pomegranate, that is, had become the bride of Pluto, she was obliged to return below and spend one-third of the year with her husband, remaining topside with her mother the other eight months. Ceres now allowed the earth to bring forth fruits. Proserpina, who disappears and then returns to her mother Ceres, is traditionally considered to be the seed, which remains hidden in the ground part of the year, then rises from the ground and nourishes men and animals.

I find especially interesting the symbolism of the red pomegranate, which I believe stands for Proserpina's virginal blood. This suggests a relation to the story of Adam and Eve in Genesis, where the red apple (in all probability a red pomegranate) stands for Eve's loss of sexual innocence, "the fruit of the tree of knowledge." Michael Pollan observes that some scholars think the biblical "apple" in the Garden of Eden was in fact a pomegranate: "In fact, the Bible never names 'the fruit of the tree which is in the midst of the garden', and that part of the world is generally too hot for apples, but at least since the Middle Ages northern Europeans have assumed the forbiddn fruit was an apple" (20). Theophrastus, however, states that apples and pomegranates did coexist in the ancient world. In a section called "Of the plants special to northern regions," he reports: "Tmolus and the Mysian Olympus have the hazel and chestnut in abundance, and also the apple and pomegranate" (4: 4).

Helene P. Foley summarizes pomegranate lore and cautiously suggests the relation between the red pomegranate and virginal blood:

Pomegranates were associated with blood, death, fertility and marriage and may have served, at least symbolically, as an aphrodisiac. ... The fruit's double association with sexuality and death (deriving from the blood-red color and its multiple seeds) is perfect for this narrative. Persephone has eaten her husband's food among the 
dead. She may have consummated her marriage-we find her in Hades' bed, an unwilling partner (343-44) who is still longing for her mother (and hence emotionally if not physically uncommitted to sexuality). The eating of the pomegranate seed may for the reasons given above suggest sexual seduction. If so, Persephone becomes, by eating it, symbolically committed to her future husband. (56-57)

Margaret Anne Doody is less tentative. After observing that the pomegranate is a constant attribute of Persephone, and that it also appears in pictorial representations of the Virgin Mary, she concludes that "the goddess-seeking pomegranate 'represents' what it resembles, woman's genitals, considered as comprising uterus and ovaries as well as vulva and vagina" (460).

There are some interesting points of contact with Celtic mythology and its later re-elaboration in Arthurian romance. Edward Dudley reports:

In the Welsh medieval tale Culhwch and Olwen, the earliest Arthurian story, much of the action focuses on a prolonged hunt for a marvelous boar. ... [Arthur] makes an astute comment about the nature of this extraordinary animal to the effect that prior to his porcine incarnation he had been a king, but because of his sins God had turned him into a boar. The comment about sin and God sounds like a Christian re-writing of a pagan shapeshifting, a phenomenon here related to a god/hero with an alternate porcine incarnation. .. . In Celtic mythology, the swine divinity ... had great prestige and in fact was identified with Mercury by the Romans. In this Hermes/ Mercury capacity we note a curious connection to the matter of interpretation, to a hidden hermeneutic capability associated with pigs. We see remnants of this attitude in the story of the three little pigs and the apple trees. Apples, as in the apples of Avalon and in the Bible, were also associated with wisdom, knowing, and hermeneutic capabilities. . . . Arthur's comment indicates that he, as a special hero, appears to possess strange hermeneutic powers that give him access to the earlier condition of the text. This knowledge does not make him seem idiotic or funny at this stage in the development of Romance as a genre, but this capability does cause him to appear incompetent in later tales, as in the Lancelot and Guinevere story where he lets a strange challenger bargain away the possession of the queen. In that case ... Arthur appears inept, when at the level of myth his erratic behavior disguises a lost meaning in which the queen is possessed for part of the year by an alien deity or magician. (128-30; emphasis added) 
The sinful king's transformation into a boar recalls Ascalaphus' transformation into the owl. The queen's absence for a stipulated part of the year during which she keeps company with "an alien deity or magician" recalls Proserpina's similar absence during which she keeps company with her husband, the lord of the underworld. The matter of Arthur's special hermeneutic capabilities relates him to the figure of the owl in the Soledades. Now, this is interesting and suggests that the story of Ascalaphus plugs into a wider concern for forbidden knowledge or, in Dudley's terms, special hermeneutic capabilities. However, there are so many other references to the Ascalaphus story and the properties of the owl in Góngora's own cultural-intellectual milieu that the Celtic mythology-Arthurian romance connection is not essential to the presence of the Ascalaphus story in the Soledades.

The family structure (Ceres and Prosperpina as mother and daughter, Pluto as daughter's husband, initial antagonism replaced by modus vivendi) ought to be important, as such family relationships seem always to be important to Góngora. Proserpina and Ceres vs. Proserpina and Pluto yields a triangle comprising Ceres (mother) vs. Pluto (husband) as rivals for Proserpina. ${ }^{1}$ However, this aspect of the story is not developed overtly in the Soledades.

The sexual seduction of Proserpina figured as the eating of a forbidden fruit so similar to the apple of Eden, similarly figuring the loss of innocence (another term for sexual seduction) of Eve, is present but not elaborated. It has been widely observed in this context that Góngora's poem begins with the story of another abduction and loss of innocence perpetrated by "el mentido robador de Europa," so that the theme of sexual seduction and loss of innocence can be seen to underlie the entire poem.

In Góngora, the most important overt feature is the transformation of the witness Ascalaphus into the owl. Ascalaphus was the son of Acheron and Gorgyra or Orphne. When Pluto gave Proserpina permission to return to the upper world, provided she had eaten nothing (i.e. had not lost her virginity to him), Ascaphalus declared that she had eaten part of a pomegranate. Proserpina, in revenge, changed him into an owl, by sprinkling him with water from the river Phlegethon. In view of the symbolism of the pomegranate, we can conclude that what Ascalaphus observed was the act of intercourse, a variation on the primal scene.

The story is told first (?) in the Homeric Hymn to Demeter, but there is no reference to Ascalaphus. Góngora's source is most probably Ovid, who tells it in Fasti 4. 607-08, and Metamorphoses 5. 341-560, where Ascalaphus appears in vv. 533-49. Covarrubias in the Suplemento has an entry under Ascalafo that summarizes Ovid's version: "Fue hijo de 
Acheronte y de Orphenes. Convirtióle en buho la diosa Ceres, indignada de que depusiese contra su hija Proserpina haber comido en el infierno una Granada, y con esto no tener lugar la gracia que Júpiter le había hecho de que la pudiese sacar del infierno con tal que no hubiese desayunado en el infierno de ningún manjar. De aquí quedóse el buho ave funesta y aborrecida." For reference, here is Ovid's text:

And Ceres, as he ended, was determined to have her daughter back, but the Fates forbade it.

She had been hungry, wandering in the gardens, poor simple child, and plucked from the leaning bough

a pomegranate, the crimson fruit, and peeled it, with the inside coating of the pale rind showing, and eaten seven of the seeds, and no one saw this but Ascalaphus, son of Orphne, dark bride of Acheron. He saw, he tattled, so she could not return, and she, in anger, turned him into a bird, of evil omen, dashing hell-water in his face, to give him a beak, and feathers, and big round eyes, and wings all sulphur-colored, a head enlarged, and talons, and a dull way of moving, so he barely shudders his feathers, sluggish, a bad omen to mortals, the foul screech-owl.

He deserved it for being such a tattle-tale. (5. 533-49)

The story of Proserpina and Ascalaphus appears, fragmented, in various places toward the end of the second Soledad, during the hawking party, beginning at verse 791. As we have seen, the owl is evoked in terms of the Proserpina story, with reference to "el bello robo de la stigia Deidad," to "Ascálafo," and to "el deforme fiscal de Proserpina." At the end the owl is "el testigo que en prolija / desconfianza a la sicana Diosa / dejó sin dulce hija, / y a la stigia Deidad con bella esposa."

The owl brings up the rear of the aristocratic party. His physical attributes are his size, his ponderous heaviness, and his topaz-colored eyes which the other birds envy.

Grave de perezosas plumas globo, que a la luz lo condenó incierta la ira del bello de la stigia Deidad robo, desde el guante hasta el hombro a un joven cela; esta emulación pues de cuantos vuela por dos topacios bellos con que mira, término torpe era de pompa tan ligera. (791-98) 
The owl takes flight and alights on a sea-hardened outcropping of earth, where he is set upon by a swarm of envious crows:

En sombra tanta

alas desplegó Ascálafo prolijas

verde poso ocupando,

que de césped ya blando

jaspe lo han hecho duro blancas guijas.

Más tardó en desplegar sus plumas graves

el deforme fiscal de Proserpina,

que en desatarse, al polo ya vecina,

la disonante niebla de las aves:

diez a diez se calaron, ciento a ciento,

al oro intuitivo, invidiado

deste género alado,

si como ingrato no, como avariento,

que a las estrellas hoy del firmamento

se atreviera su vuelo,

en cuanto ojos del cielo. (886-901)

Liberated from the crows, the owl takes flight as the poem ends:

Con sordo luego estrépito despliega

(injurias de la luz, horror del viento)

sus alas el testigo que en prolija

desconfianza a la sicana Diosa

dejó sin dulce hija,

y a la stigia Deidad con bella esposa. (974-79)

As we have seen, the owl is evoked in terms of its physical characteristics and of its relations with other birds. Covarrubias provides a skeleton of the ornithological-mythological corpus available to the poet: "Ave nocturna, infeliz y de mal agüero, de vuelo corto y que vive en cavernas y edificios arruinados. ... Escriben los poetas haberse convertido en esta ave Ascalafo, hijo de Acheronte, por la indignación que tuvo contra él la diosa Proserpina, testificando haber comido de una granada que cortó del árbol después que bajó al infierno, robada de Plutón. Ovidio libro 5, Metamorfoses. ... Del búho se aprovechan los cazadores, poniéndole en parte que pueda ser visto de las demás aves, las cuales como a cosa no vista acuden a cercarle, y algunas a sacarle los ojos." The aristocratic hunters in Góngora's poem "del búho se aprovechan."

The Diccionario de Autoridades insists again on the owl's eyes and on the enmity between owls and crows. This relationship is crucial to the narrative ending of the Soledades, where the owl is in fact attacked 
by a swarm of crows: "Ave del tamaño del águila: el cuello más corto, y también las plumas, que son variadas de negro, pardo y amarillo. La cabeza grande y redonda, con unas plumas altas en forma de orejas. Los ojos mayores y más resplandecientes que los de todas las demás aves. ... Es nocturna, sirviéndole sus ojos de antorcha en la oscuridad. Los cuervos y los búhos habían entre sí muy gran contienda, pero los cuervos eran en mayor queja cá [sic] los búhos."

The cuervo, demoted to its female form cuerva, is evoked in Góngora's poem terms of a series of negative attributes: her black color, the "luto" that "infamó la verdura con su pluma," her "siniestra voz" individually, and the "disonante niebla" of the group, and her envy of the "oro intuitivo" of the owl's eyes, the "dos topacios bellos con que mira."

In the poem, the solitary owl accompanying the hawking party is attacked by a swarm of crows and rescued by a pair of the aristocratic raptors. The crow notices the owl and convokes her envious colleagues.

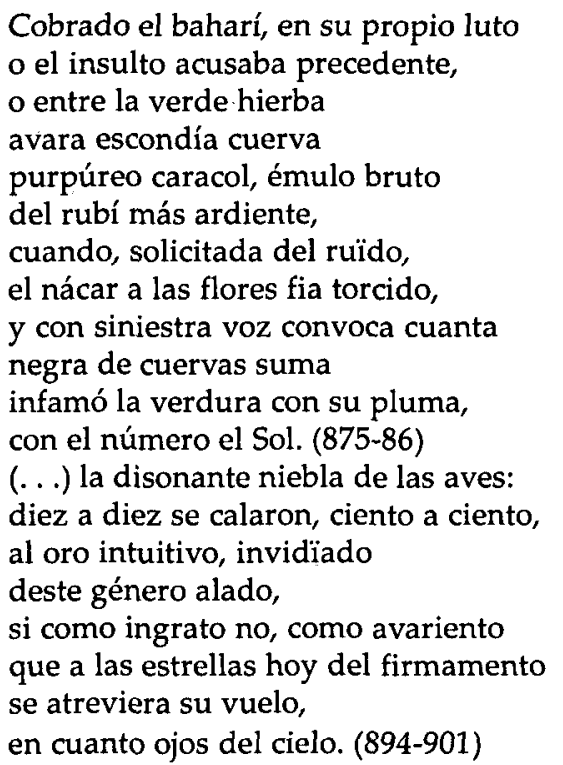

One crow now comes to stand synechdochally for the entire swarm. The gerifalte and the sacre catch this suddenly hapless crow between them and destroy her. She is likened first to a heavenly body trapped between the limits of the tropics of Cancer and Capricorn, and then to a tennis ball batted between two players and finally punctured: 
Poca palestra la region vacía

de tanta invidia era, mientras, desenlazado la cimera, restituyen el día

a un girifalte, boreal Harpía que, despreciando la mentida nube, a luz más cierta sube, Cénit ya de la turba fugitiva. Auxiliar taladra el aire luego un duro sacre, en globos no de fuego, en oblicuos sí de engaños mintiendo remisión a las que huyen, si la distancia es mucha (griego al fin). Una en tanto, que de arriba descendió fulminada en poco humo (902-16) (. . .) Breve esfera de viento, negra circunvestida de piel, al duro alterno impulso de valientes palas, la avecilla parece $(923-26)$ (. . .) Tirano el sacre de lo menos puro desta primer región, sañudo espera la desplumada ya, la breve esfera, que, a un bote corvo del fatal acero, dejó al viento, si no restituïdo, heredado en el último graznido. (931-36)

Covarrubias is extensive and impassioned on crows. In fact, the dictionary article on the "cuervo" provides the key to what I believe is the meaning of the ending of the Soledades, as an allegory of poetry and society in general, and of Góngora and his society in particular.

In a luminous article on birds in the Soledades, Nadine Ly quotes Covarrubias's article on "cuervo," but for reasons of space she stops short of making the connections I want to belabor here: "L'espace manqué ici pour rappeler les articulations essentielles du très long article que Covarrubias consacre au courbeau" $(168, n .12)$. Suffice it to say that the present study would be impossible without Professor Ly's observations.

The lexicographer begins with the refrán "Cría el cuervo, y sacarte ha el ojo." This leads to the observation that "los cuervos acuden a sacar los ojos y aun los sesos a los ahorcados." Ly recalls the proverb and observes that "le poème les dote d'une cupidité rapace qui les pousse à attaquer le hibou pour ses yeux d'or" $(168, n$. 12). Marsha Collins also discusses the crow's desire for the owl's golden eyes, but reads it as an allegory of the crow's morally reprehensible greed: "her quest for riches meets with disaster ... The poet packs a didactic mes- 
sage in this emblematic scene-an admonition regarding the dangers of avarice, one of the seven deadly sins" (80-81).

Covarrubias begins to exploit the crow's anthropomorphic attributes: "El cuervo es ave que imita la voz humana.... Compararon los egipcios ... los aduladores a los cuervos ...; porque el cuervo saca los ojos corporales al hombre muerto que halla en la horca, y el lisonjero adulador saca los ojos del alma y del entendimiento al hombre vivo ... Hasta en los nombres tienen semejanza, porque el cuervo se llama en griego choras y el adulador cholas, y jugando con el vocablo dijo Diógenes que más quería tratar con cuervos que con aduladores."

About here the article on crows becomes an active meditation on the situation of poetry and poets in the years immediately preceding publication of the Soledades:

Cosa vergonzosa es, que siendo esta verdad tan notoria no escarmentemos, y que ya no se favorezca la virtud ni las letras, y sólo medren con los príncipes los chocarreros y hombres de placer; y una guitarra de cinco cuerdas en manos de un loco sea de más provecho que todas las siete artes liberales en el entendimiento y seso de un hombre cuerdo. Y es esta causa bastante para desterrarse voluntariamente de las cortes de los príncipes los hombres de prendas, como cuenta de sí Marcial haberlo hecho... Y no por esto se desvanezcan los poetas que hoy día se usan en la Corte, especialmente los que hacen sus poesías y ellos mismos se las cantan, porque son enjertos en los que acabamos de reprobar: hombres sin letras, sin entendimiento, puros romancistas, copleadores de repente y trobadores de pensado y en todo tiempo ignorantes. Estos han infamado la poesía de manera que los hombres que pudieran ilustrar la lengua española con la imitación de los poetas latinos y griegos no osan publicar sus trabajos, porque no los juzguen por livianos y de poco juicio, como son los que comúnmente se admiten.

Covarrubias reminds his reader that both the cuervo and the cisne were sacred to Apollo. This would make the crow a rival of the swan for Apollo's favor. In Cervantes's Galatea (1585) the good poets are figured as "blancos y canoros cisnes," while the bad ones are "roncos y negros cuervos." The cisne/poet connection is already figured in Alciato. José Miguel Oltra Tomás recalls:

El cisne figura ya en Alciato como símbolo de los poetas ... emblema que inspiraría a Carballo su Cisne de Apolo. Diego López, comentando el 'Insignia Poetarum' de Alciato, escribe: 'Dice Alciato que unos tienen por blasón una serpiente, otros un león, pero que estos animales no están bien para los poetas, sino el 
Cisne, ave de Apolo ... Y porque son consagrados a Apolo, Dios de los adivinos, cantan tan suave y dulcemente, cuando quieren morir, como adivinando los bienes de la otra vida. Semejante a un cisne podremos llamar a un santo cuando muere, el cual muere contento porque espera que va a gozar de los bienes de la vida eterna. $(230$, n. 83$)$

Góngora replaces the cuervo-cisne opposition with the cuervo-búho, and of course eliminates all the religious significations. For our purposes, his substitution suggests a different concept of poetry, not the "dulce cantar" of the cisne, but the penetrating vision of the búho. ${ }^{2}$

Nadine Ly cites Pérez de Moya, Filosofia secreta on Ascálafo: "Por Ascálafo quieren los poetas significar la condición de los acusadores y no otra cosa, según dice Juan Bocacio, por cuánto Ascálafo acusó a Proserpina que había comido de los frutos del infierno, y así le convirtieron en tal cosa, que significase las condiciones de los acusadores, y dijeron que era hijo de Acherón y de la ninfa Orna. Acherón significa "tristura" o "sin gozo" . . la ninfa Orna significa "sepultura" (164). She goes on to relate that Pérez de Moya also reports that Ascálafo was the first philospoher of Antiquity to demonstrate that the moon, lower in the heavens than the other stars, is visiting the underworld when she is absent from the sky. She is even called Proserpina during that time. Ascálafo was transformed into an owl because, like the owl, he passed his nights studying the moon. (i.e. Proserpina and her strange behavior.) Like the owl, the philosopher is withdrawn, not inclined to pleasure, his activity is nocturnal and the ardor of study consumes him. Finally, if the owl is a bad omen, the sage resembles him in that he sees into the future and his predictions are frequently unpleasant or unwelcome. Ly then suggests an equation, which Pérez de Moya stops short of: if both the stool pigeon and the sage resemble the owl, and for the same reasons, then they must also resemble each other (165). This brilliant insight is introduced only to be quite explicitlydenied in the next sentence: "Ce n'est pas autour de ces questions, il faut affirmer d'emblée, que se construit la hibou de la deuxième Solitude" (165). She does allow that the mixture of attraction and repulsion joined in the owl is "not without relation" to the double figure of the informer and the sage evoked by Pérez de Moya. Then she cites Pedro Salinas, who insists on the owl as emblematic of wisdom, sacred to Pallas Athena etc, only to reaffirm that the owl in the Soledades is "encore différent, posé comme une énigme" (167).

Autoridades recalls a degraded version of the Ascálafo-búho story current in sixteenth-century underworld slang: "En la germanía [búho] significa el descubridor o soplón. Juan Hidalgo en su Vocabulario de germanía (1609). Latín delator." Again Autoridades: “'Es un búho.' Se 
suele decir de la persona que no gusta del comercio de las gentes, y vive retirada."

It cannot be a coincidence that Soledades ends with the witnessAscalaphus-owl taking flight, when the Soledades as a whole is the record of the witness-peregrino and what he sees. The peregrino's status as witness is attested by Don Juan de Jáuregui, who criticizes him on various counts, among them that "él no sirve sino de mirón." This suggests some connection between the peregrino and the búho Ascáfalo.

Antonio Vilanova explicitly relates the peregrino to an allegory of the poet and to the peregrino of byzantine narrative. On the importance and universality of the figure of the pilgrim in narrative fiction: "A partir de Il Filocolo de Boccaccio, y en una larga trayectoria que va desde Il peregrino de Jacobo Caviceo a la Selva de aventuras de Jerónimo de Contreras, al Peregrino en su patria de Lope, al Persiles y Sigismunda de Cervantes, y que llega hasta el Criticón de Gracián, el peregrino, convertido en símbolo de la condición humana, aparece reiteradamente como protagonista de la ficción novelesca" ("El peregrino andante" 331). And specifically with relation to the Soledades: "Este personaje, ya existente en la poesía italiana y española del Renacimiento como personificación alegórica del poeta enamorado, es el peregrino de amor. Símbolo de la condición humana, arquetipo del hombre barroco, víctima del desengaño amoroso y absorto caminante por la soledad, el peregrino de amor es el único personaje novelesco que podía protagonizar la grandiosa concepción simbólica de las Soledades" ("El peregrino de amor" 419 ). What Vilanova does not mention is the peregrino as an allegorical personification of the poet as poet. This is Góngora's great contribution: to combine or conflate the peregrino as lover and the peregrino as artist, already explicit in the dedication to the Duque de Béjar, the famous "pasos de un peregrino" so ingeniously explicated by Mauricio Molho (52-58).

In a well documented and carefully reasoned article on the (Byzantine) narrative models of the Soledades, Antonio Cruz Casado argues that from the initial reception of the Soledades in 1613 the peregrino of Góngora's poem was identified with the peregrino-protagonist of what is normally called the Byzantine romance but which Cruz Casado, following López Estrada, prefers to call "libros de aventuras peregrinas" (70). He cites Pedro Díaz de Ribas, Discursos apologéticos por el estilo del "Polifemo" on the subject matter in general: "Así en estas Soledades, si miramos el modo de decir, se ha de reducir al sublime; si a la materia, a aquel género de Poema de que constaría la Historia etiópica de Heliodoro si se redujera a versos" (82). He also cites Francisco Fernández de Córdoba, Abad de Rute, in his Examen del Antídoto, responding to 
Jáuregui's criticism that Góngora's peregrino has no name: "pues Heliodoro en buena parte de su Historia etiópica nos hizo desear los nombres de la doncella y del mancebo, sujetos principales del Poema." Cruz Casado concludes: "en nuestra opinión, en la mente de algunos escritores del momento se había establecido cierta relación entre la obra de Heliodoro, junto con sus secuelas en la literatura narrativa española, y ciertos rasgos de la creación gongorina" (80).

Certain epico-byzantine formal characteristics are present in the Soledades, and other contemporary works: the beginning in medias res with a shipwreck, for example, from Virgil to Lope, El peregrino en su patria (1604). Cruz Casado notes that Avalle-Arce had already observed the similarity between Lope and Góngora, and concludes: "creemos que no se trata de una simple coincidencia, sino que ambos emplean un mismo recurso técnico, tomado de los modelos clásicos. Y quién sabe si en el fondo de ello no se encuentra un deseo de emulación, por parte de Góngora, de un esquema literario utilizado antes por Lope y conocido por don Luis, mejorado sensiblemente y de manera originalísima en la creación gongorina" $(89, \mathrm{n}$. 66). This splendid insight is buttressed by the well-known enmity between Lope and Góngora.

A particularly interesting instance of the presence of "libros de aventuras peregrinas," and one that is crucial for the comprehension of the Soledades, is the passivity of both Góngora's peregrino, whom Jáuregui had dismissed as a mirón instead of a protagonist, and Luzmán in Contreras' Selva de aventuras (1565 and 1583): "Algo parecido ocurre en las Soledades; el peregrino, al que Jáuregui había llamado mirón, es nada más que una especie de espejo por medio del cual tenemos acceso a una serie de escenas, diálogos o historias, sin relación alguna con su naufragio" (90).

Finally, Cruz Casado follows up on María Rosa Lida's rather infecund relation of the Soledades to Dión Crisóstomo, not to the narrative Historia del cazador de Eubea that is so very different, but to another treatise, translated by Góngora's friend Pedro de Valencia and entitled Perianachoresos, which Valencia translates as Del retraimiento (or, one might say, De la soledad). Dión's thesis is that "no es fácil vencer [los estorbos], ni se puede sacar cosa de provecho, sino es en las soledades y sosiegos" (Valencia's translation).

The búho-peregrino-poeta nexus begins by way of Covarrubias's article on "cuervo." Here the crow is explicitly equated with the adulador by their common activity of taking the eyes of the virtuous. The virtuous are then identified as the good poets. Good poets (e.g. Martial) voluntarily exile themselves from Court, because they are not valued. Good poets are then described exactly as we describe Góngora. 
Pérez de Moya among other sources offers analogies between Ascálafo, the philosopher and the owl as lovers of solitude and as revealers of hidden truths. The witness-owl-Ascálafo is identified as acusador, in opposition to the crow as adulador. Góngora's detractors and defenders alike observed from the beginning the analogy between the witness-peregrino in the poem and the witness-protagonists of Byzantine narrative fiction.

All that is missing is the other side of the equation, the relation between búho, 'delator (de verdades),' the peregrino in the poem, and Góngora himself. Michel Moner comes very close to identifying the peregrino in the poem and the poet, and to identifying the poem as a narrative. He evokes a story untold, the peregrino's story, who he has been and what he has done before the poem begins, a "vécu": "Mais de qui s'agit-il? Du protagoniste? Du poète? Ou des deux à la fois?" (198). Antonio Carreira considers the identification of the peregrino with Góngora to be self-evident: "quien huye del tráfago urbano y de sus pompas engañosas [es] el poeta peregrino que es Góngora, o el peregrino poeta, que es su personaje." He further observes that the "vivencias de 1609 " were present at the genesis of the Soledades (269).

Emilio Orozco has written, with more passion than precision, on the events of 1609 as the proximate cause of the composition of the Soledades.

Una fecha para nosotros clave del más profundo cambio psicológico y sobre todo el más fecundo como impulso por sus consecuencias en la creación poética. Esa fecha es la de 1609. (233)

No había destacado la crítica gongorina lo decisivo que es para la vida espiritual y literaria del poeta, el desengaño por el revés sufrido en la corte en esos momentos. (234)

Señalábamos estos años que se inician en $1609-1610$ y se cierran con su marcha a la Corte en 1617 como los que corresponden ... a un más tranquilo vivir del poeta. (231)

Cruz Casado summarizes: "Como es sabido, hacia 1609, don Luis abandona la corte marcado con una profunda decepción; sus aspiraciones personales de medro y aceptación en los nobles círculos madrileños se han venido abajo. Todo ello genera un cambio psicológico en su carácter, lo que da origen a un ideal de apartamiento de la vida ruidosa y vana de la corte que configura en cierto sentido el gran poema gongorino" (73). Jammes argues that within the context of the general opposition of corte and aldea, Góngora considered that the court was not only physically and morally, but also politically reprehensible. Madrid is not only the site of a ridiculous and polluted river, and the meeting place of a frivolous and morally corrupt aristocracy; it is also 
the place where not infrequently disastrous political decisions are made. One of the worst, the expulsion of the moriscos, was reached precisely in 1609. It was a policy Góngora greeted with "une ironie supérieure" (133).

There was also the negative verdict concerning the death of his nephew, Francisco de Saavedra, the elder son of the poet's sister Francisca. The young man was wounded in a street fight in 1605 . He died after all medical intervention, including trepanage, proved futile. His mother brought suit against those responsible, in both the civil and the Inquisitorial courts. The legal proceedings dragged on for four years, with the final rulings unfavorable to the family. Indeed, Góngora's presence in the capital in 1609 is in part attributable to his unsuccessful efforts to influence the outcome. Dámaso Alonso summarizes: “Don Luis se había visto tratado con poca simpatía y atención en las oficinas de justicia, había tenido que soportar el desvío y el retardo quizá malévolo del relator, y buscando un favor, una protección, que no había llegado, habría tenido que formar en esos acompañamientos adelantados (que no séquitos) de los consejeros y de los ministros. $Y$ nos le imaginamos teniendo que adular y esperar a los señores del Consejo de la Inquisición" (116).

In 1609 Góngora also had to endure the failure (along with Cervantes) to be included in the retinue of the Conde de Lemos when he became viceroy of Naples. This failure specifically contrasts Góngora as poet with such mediocrities as the Argensola brothers, and plays directly into the cuervos-búho opposition in the Soledades. Dámaso Alonso and Jammes have both studied the sonnet "El conde mi señor se fue a Nápoles," that offers a reaction to the rejection. Jammes mentions the Argensolas specifically: "Nous y retrouvons aussi son humeur médisante, qui s'exerce ici aux dépens d'autres écrivains, et principalement, semble-t-il, de Argensola, en une phrase anodine oú transparaît son dédain ironique: 'Como sobran tạn doctos españoles'" (219).

In short, there was every reason to leave Madrid in 1609 and seek the solitude of the south. Orozco summarizes: "Así, cuando vuelve asqueado y malparado de la corte,... [h] uye del trato de las gentes, fuera de ese grupo de amigos poetas admiradores que mutuamente se estimulan para superar perfecciones en el saboreo de la tranquila creación literaria. ... Ese sentimiento de menosprecio de Corte incluyendo no solo a sus señores, sino también a sus poetas - persistió en Góngora aún después de haber lanzado a ella, desafiante, sus Soledades" (243).

With this extensive preamble now ambled, we can come, finally, to the Andalusian hawking party in the poem, where the raptors save 
the owl, and provincial aristocracy saves the poet.

According to Jammes, contemporaries believed the aristocrat of the hawking party was either the Duque de Béjar (dedicatee of Soledades) or the Conde de Niebla (dedicatee of Polifemo; see his Soledades 65-73; $544,546)$. Antonio Carreira assumes it is Niebla, "a quien el poeta visitó en 1607, dedicó el Polifémo en 1612, y retrata al final de la segunda Soledad" (219). My money is also on Niebla (a Guzmán, who would become the $8^{\text {th }}$ duque de Medina Sidonia), because of the locationpaysage, and because of the poem's promotion of this local Andalusian aristocrat to royal status, or deserving of royal status. Antonio Domínguez Ortiz has written on the conspiracy of $8^{\text {th }}$ duque de Medina Sidonia to declare independence from Castile and make himself king.

The Polifemo is dedicated to Don Manuel Alonso Pérez de Guzmán el Bueno, conde de Niebla. He was the son of Alonso Pérez de Guzmán el Bueno, $7^{\text {th }}$ duque de Medina Sidonia and Cervantes's bette noire. Góngora's dedicatee became the $8^{\text {th }}$ duque de Medina Sidonia upon his father's death in 1615, on which occasion Góngora wrote the Égloga piscatoria (Millé 404). He was the one who married Juana de Sandoval, daughter of the Duque de Lerma (Espinosa 226-30). The "prólogo al lector" of Pedro Espinosa's Elogio al retrato del excelentísimo Sr. D. Manuel Alonso Pérez de Guzmán offers a genealogy of the house of Medinasidonia (Jammes 279-82 w/ notes).

Pedro Espinosa clearly believes the aristocrat in the hawking party is don Manuel Alonso, the dedicatee of the Polifemo. First, Espinosa identifies don Manuel as a great falconer: "Si vuela halcones, de tantos y tan puntuales criados se sirve en el cielo como en la tierra: tal, que siendo conde [de Niebla], mereció título de cazador mayor de su Majestad" (233). Second, Espinosa describes a corte-aldea relationship in the Conde that recalls Góngora's, and in the course of it he explicitly identifies the falconer in the Soledades as the Conde de Niebla:

Cuando más se debía a los ojos y voluntades de la Corte, por ser su grandeza, ornato, regocijo, gala, alabada (igran cosa!) de la misma ambición cortesana, cuando su suegro el de Lerma mandaba al mundo, sordo a sus ruegos y promesas, trató retirarse a la soledad [sic!] de Huelva, diciéndole: "Tanto harta, señor, una fuente como un río. La Corte, donde toda la vida es corta, quiere lejos, como pintura del Greco; si bien no tanto que enfríe, mas ni tan cerca que abrase. Aquí los favores se ríen de los méritos, y por grandes peligros se llega a otros mayores. Ya ve $V$. E. que el vivir no quiere prisa, y que no es poca cordura llegar al escarmiento antes que al daño. Cuanto al lugar, yo le hago, no él a mí, adonde llegarán las nuevas viejas, y no por eso peores. Al fin, no está rendido el que no ruega." En esta soledad [sic] le halló el príncipe de los poetas don Luis de Góngora cuando 
dijo: “En sangre claro y en persona augusto, / si en miembros no robusto, / Príncipe le sucede, abrevïada / en modestía civil real grandeza" [Soledad 2.809 ss]. Y en su dos veces grande Polifemo: "Estas que me dictó rimas sonoras." (251-52)

Jammes points out that Góngora was always trying to curry favor with Lerma's relatives. The conde de Lemos (the 1609 disaster) was Lerma's nephew and son-in-law. The conde de Niebla was also Lerma's son-in-law, and was closely related to the marqués de Ayamonte and the duque de Béjar (286). The relation is the following. The sister of don Alonso Pérez de Guzmán el Bueno, $7^{\text {th }}$ duke of Medina Sidonia, was doña María de Guzmán. She was married to don Francisco de Zúñiga, duque de Béjar. She was therefore also the aunt of Góngora's dedicatee, don Juan Manuel Alonso Pérez de Guzmán, $8^{\text {th }}$ duke of Medina Sidonia. Jammes also observes that Góngora was always ambivalent, that on the one hand he wanted to be a courtier, and on the other he turned his back on it. And, says Jammes, this duality is fundamental for the Soledades (287). According to Anne Cruz, John Beverley

discerns in Góngora's relations with the duke of Medina Sidonia, to whom the poet dedicates the Soledades [sic], an implicit alliance between the anti-mercantilist aristocracy and the direct producers of agriculture outside the marketplace with whom Góngora identifies. ... Beverley quite rightly points out that Góngora's tropes of nature constantly counterpose use value to exchange value. ... Yet Góngora could not-and indeed did not-remove himself from this market place. His desire to participate within the system under the protection of Medina Sidonia inevitably returns the solitary pilgrim [another offhand identification of Góngora as the "solitary pilgrim"] to Court, where he writes the obsequious Panegírico al duque de Lerma, through whose favor he receives a royal chaplaincy. (86)

The question now becomes what is the relation in the poem between the solitary butho, who clearly stands for the poet, and the other raptors in the employ of the aristocratic hunter whom we can now identify as the Conde de Niebla. The other raptors make short work of the noxious crow, and at the conclusion of their intervention the buho begins his solitary flight. Does this mean that the poet expects the Conde to protect him from the cuervos/bad poets/aduladores? It would certainly seem so. This hypothesis works perfectly, and this is the modest conclusion toward which this article has been so ponderously straining since its beginning. Furthermore, this reading allows us to identify the last verses of the second Soledad as the end of the poem, in dis- 
agreement with the prevailing critical orthodoxy. The owl taking flight is emblematic of the poet, liberated from his persecutors, embarking on a new period of major artistic achievement in a secure environment. The end narrated here takes place in a fictional 1609. It is a beginning for the poet, of the four years from 1610 to 1614 which Orozco identifies as the most productive in the poet's career, in which he wrote a full $40 \%$ of his work, including the two plays, the Polifemo and the Soledades.

What, then, to make of the following apparently incomprehensible lapsus calami? The dense cloud of crows that pursue the buho is described as "la disonante niebla de las aves" (894). Among the commentators, Salcedo Coronel finds the metaphor conceptually coherent but otherwise unremarkable: "D.L., que habiendo llamado niebla a la grande suma de cuervas, por la multitud y lo oscuro de su pluma, dice luego que se desató, que es voz que corresponde a la alusión [the niebla], porque comúnmente decimos que se desata la niebla, cuando se deshace" (ed. Jammes 564, n. 893). Nobody seems to have observed the pun on the name of the savior of the búho-poet from the cuervaspoetasters. If the word niebla is in fact a pun, the celebration of the Conde is severely compromised. I see two possibilities for resolving the dilemma.

Perhaps this is some kind of reference to Góngora's disappointment over the events of 1609 , involving not the Conde de Niebla, but the Conde de Lemos, who was related. This would mean that the topography described in the text really belongs in Galicia, as Hermann Brunn proposed in 1934, following a suggestion in Artigas to the effect that the second Soledad contains reminiscences of the ill-fated expedition to Monforte. Jammes summarizes, and disagrees: "Es cierto que el paisaje gallego, y más concretamente el de la ría de Pontevedra (que Góngora tuvo tiempo de admirar en su viaje de 1609 a Monforte) es en España el único cuya variedad ... podría concordar con la de las Soledades, pero de las dos partes del poema, y no sólo de la Segunda" (Soledades 65 , n. 56). Jammes (along with Carreira) rejects the Brunn hypothesis, but that does not mean it should not be revisited.

Or perhaps the apparent celebration of the Conde de Niebla is more than unidimensional. There is a double ambiguity here. First, the cuervas (the villains) are called by the hero's name (niebla), and second, both the cuervas and the búho are described in similar terms, eliminating or severely curtailing the difference between sympathetic and unsympathetic characters. The búho is introduced as "grave de perezosas plumas globo" (791). The lone cuerva who stands synechdochally for the whole crowd of them is called "breve esfera de viento, negra circunvestida piel" (923-24). Globo and esfera are quite 
similar; in fact, Autoridades makes them synonymous, especially as they refer to both geography and astonomy. But there are significant differences. The globo in the poem is solid ("grave, de perezosas plumas") while the esfera is full of wind, and is batted back and forth like a tennis ball between two raptors. In addition, the owl and the crow are different in other ways we have already observed. The globoesfera pair can be explained away (maybe), but that still leaves the niebla of crows. Maybe niebla refers only to the black color of the crows' plumage (niebla < tiniebla), and Don Luis really was not thinking of its other meaning. But I find it difficult to believe that he was unaware of his own pun.

In the poem, the búho is saved from a niebla de cuervas by the conde de Niebla. This means that there is a niebla that dissipates niebla. The Conde fulfills this function in the dedication to Polifemo: "ahora que de luz tu Niebla doras." His presence at Niebla illuminates, dissipates the niebla.

On balance, I am inclined to think that these ambiguities really are not so ambiguous. Niebla can be seen to function as it does in Polifemo, and the globo and the esfera are well differentiated. Well differentiated, but undeniably and indelibly present. Perhaps the Conde can be simultaneously the poet's protector and his detractor, and maybe the búho and the cuerva are uncomfortably similar after all. Maybe the poem is not the success story I have described here. Crystal Chemris describes the Soledades as "a kind of Möbius strip, a frustrated circuit endlessly repeating a story of loss and ontological isolation" (154-55). I am not sure about the loss and ontological isolation, but I would retain the image of the Möbius strip, with both sides, both incompatible readings, continuously visible.

What we know or suspect concerning the dates of composition may provide at least a context in which the ambiguities and incompatibilities may be situated. As we have seen, the first Soledad is the product of the poet's flight from Court following the disastrous events of 1609, and his seclusion in solitude in Córdoba. In 1613 he unleashes the poem on the Madrid audience, is met with a round of criticism and rejection, and the polemic is on. Orozco summarizes:

Si el poema había brotado en un noble y espiritual anhelo, lo de apartamiento, de desengaño y huida de la Corte y de su masa vulgar e intrigante de caballeros y de poetas, no debió de entregarlo a ella para sufrir las dentelladas de esa misma gente de la que se apartaba desdeñoso. ... Se comprende que, aunque reaccionara . . . con violencia frente al grupo de madrileños ..., el poeta abandonó la idea de continuar el poema y por lo pronto se abstuvo de divulgar lo que tenía hecho de la segunda parte. Incluso después de haber 
quedado a su favor la polémica ... tampoco entonces quiso terminar el poema, ni siquiera esa segunda parte hecha ya casi totalmente. (249)

In 1617 the poet returned to Madrid and became a part of that very culture of courtly intrigue he had fled in 1609. For Orozco, the ability to embrace what he had earlier rejected signals a psychological change so profound as to render impossible the completion of the Soledades.

Jammes offers some crucial details that modify this extreme position. The existence of the Vicuna text, which ends at verse 840 , demonstrates that Góngora continued working on the poem after his return to Madrid in 1617. The Vicuna text introduces the hawking party and in particular the Conde de Niebla, but it ends before the attack on the owl and his rescue by the raptors. Jammes conjectures plausibly that the episode of the hawking party up to verse 936, "heredado en el ultimo graznido," that is, with the destruction of the crow by the raptors, was completed shortly after Góngora arrived in Madrid. The last 43 verses, ending with the owl's solitary flight, were added later, some time between 1619 and 1626 (Soledades 19-21). In other words, the brief panegyric to the Conde belongs to the solitude of Córdoba, but the ambiguities we have noted - the pun on niebla and the similar descriptions of butho and cuervas - belong to the conflicted period of return to the Court and the embrace of what had been so repugnant in 1609. My concluding hypothesis is that the overall plan of the narrative continues the up-beat allegory of the brilliant, intellectual poet protected from his detractors by the Conde de Niebla, and that the ambiguities reflect the poet's more recent insecurities concerning his own identity and character, and his relation to the literary culture of the Court. I argued above that Góngora could not have remained unaware of the ambiguities; the foregoing suggests that their presence is indeed the visible sign of a repressed unconscious conflict.

\section{Notes}

'This dynamic is studied by Helene P. Foley in her edition of the Homeric Hymn to Demeter. Also in the same volume (which might be described as a kind of feminist reivindicación of Demeter and Persephone), see Marilyn Arthur on "Politics and Pomegrantates," and Nancy Choderow on "Family Structure and Feminine Personality."

${ }^{2}$ This opposition is recouped in the twentieth century. by Enrique González Martínez in "Tuércele el cuello al cisne," where he opposes the owl to modernismo's iconic cisne and himself to Rubén Darío. 


\section{Works Cited}

Alonso, Dámaso. "La muerte violenta de un sobrino de Góngora." Cuadernos Hispanoamericanos 158 (1963): 83-116; also in Obras completas, v. 6.

Beverley, John. Aspects of Góngora's "Soledades". Purdue University Monographs in Romance Languages, 1. Amsterdam: John Benjamins, 1980. . "The Production of Solitude: Góngora and the State." Ideologies and Literature 13 (1980): 23-41.

Carreira, Antonio. Gongoremas. Barcelona: Península, 1998.

Chemris, Crystal. "Time, Space, and Apocalypse in Góngora's Soledades." Symposium 43 (1989-90): 147-57. (1991): 7-15.

"Self-Reference in Góngora's Soledades." Hispanic Journal 12.1

Collins, Marsha S. The 'Soledades.' Góngora's Masque of the Imagination. Columbia: U of Missouri P, 2002.

Covarrubias, Sebastián. Tesoro de la lengua castellana o española. Madrid: Turner, 1977.

. Suplemento al tesoro de la lengua castellana española. Eds. Georgina Dopico Black and Jacques Lezra. Madrid: Polifemo, 2001.

Cruz, Anne J. "Art of the State: The Academias Literarias as Sites of Symbolic Economies in Golden Age Spain." Caliope 1.1-2 (1995): 72-95.

Cruz Casado, Antonio. "Hacia un nuevo enfoque de las Soledades de Góngora: los modelos narrativos." Revista de Literatura 52 (1990): 67-100.

Diccionario de Autoridades. Ed. facsímil. Madrid: Gredos, 1979.3 vols.

Doody, Margaret Anne. The True Story of the Novel. New Brunswick: Rutgers UP, 1996.

Dudley, Edward J. The Endless Text: "Don Quixote" and the Hermeneutics of Romance. Albany: State U of New York P, 1997.

Edwards, Gwynne. "The Theme of Nature in Góngora's Soledades. BHS 55 (1978): 231-43.

Espinosa, Pedro. Obras de Pedro Espinosa. Ed. Francisco Rodríguez Marín. Madrid: Real Academia, 1909.

Foley, Helene P., ed. The Homeric Hymn to Demeter. Princeton: Princeton UP, 1994.

Góngora, Soledades. Ed. Robert Jammes. Madrid: Castalia, 1994.

Jammes, Robert. Études sur l'oeuvre poétique de Don Luis de Góngora y Argote.

Bordeaux: Institut d'Études Ibériques et Ibéro-américaines de l'Université de Bordeaux, 1967.

Issorel, Jacques, ed. Crepúsculos pisando. Once estudios sobre las "Soledades" de

Góngora. Perpignan: Presses Universitaires de Perpignan, 1995.

Lida de Malkiel, María Rosa. "El hilo narrativo de las Soledades." Buenos Aires: Academia Argentina de Letras, 1964.

Ly, Nadine. "La république ailée dans les Solitudes." Issorel 141-78.

Molho, Mauricio. "Soledades." Semántica y poética (Góngora, Quevedo). (1959)

Barcelona: Crítica, 1977. 39-81.

Moner, Michel. "Une traversée des Soledades." Issorel 191-214.

Oltra Tomás, José Miguel. La parodia como referente en "La pícara Justina." 
León: Institución Fray Bernardo de Sahagún, 1985.

Orozco, Emilio, "Espíritu y vida en la creación de las Soledades gongorinas. Por qué se escribieron y por qué no se terminaron." Papeles de Son Armadans 87 (junio 1963): 227-52.

Ovid. Metamorphoses. Tr. Rolfe Humphries. Bloomington: Indiana UP, 1955. Pollan, Michael. The Botany of Desire. A Plant's Eye View of the World. New York: Random House, 2001.

Theophrastus. Enquiry into Plants and Minor Works on Odours and Weather Signs. Tr. Sir Arthur Hort, bart. Cambridge MA: Harvard UP, 1949-1961. The Loeb Classical Library, vv. 70, 79.

Vilanova, Antonio. "El peregrino andante en el 'Persiles' de Cervantes" (1949). Erasmo y Cervantes. Barcelona: Lumen, 1989. 326-409. . "El peregrino de amor en las Soledades de Góngora" (1952). Erasmo y Cervantes 410-46. 